\title{
The effect of the level of roughage during the rearing period on the utilization of food by adult cattle
}

\author{
By C. C. BALCH, R. C. CAMPLING, V. W. JOHNSON AND JILL ROY \\ National Institute for Research in Dairying, Shinfield, Reading
}

(Received I5 December 1959-Revised 4 Fanuary 1960)

In preliminary accounts of this experiment we have discussed the view, widely held by farmers and advisory workers, that cattle reared for the first 2 years or so of their lives on diets containing a good deal of roughage are able subsequently to make better use of roughages than are similar animals reared on diets containing a higher proportion of concentrates (Balch, Campling, Johnson \& Roy, 1958, 1959). This view embodies a theory that the efficiency of roughage utilization can be improved by training. The theory appeared not to have been tested experimentally, although some of the experiments carried out on methods of rearing had tended to suggest that it was invalid (Balch et al. 1959).

In the experiment monozygous twin heifers were used to find the importance of the level of roughage given during the main rearing period, extending from weaning at about $3 \frac{1}{2}$ months until first calving; the subsequent digestive ability, appetite for hay, and milk production of the heifers were observed.

\section{EXPERIMENTAL}

Animals and their management. Five pairs of monozygous twin heifers up to 3 weeks of age were collected from farms in the south of England. A sixth pair had to be removed from the experiment and slaughtered as one of its members became affected by a disorder in which the major post-mortem sign was a neoplastic condition affecting, in the main, the nasal cavities and sinuses. Details about the remaining animals and some dates of significant events in the experiment are given in Table $\mathrm{x}$. As a long period of bucket feeding is normally used at Shinfield for twins collected from farms, because of their small size at birth, the mean age of these twins when they went on to entirely solid food was 16 weeks. The twins were similarly fed before then and received $660-940 \mathrm{lb}$ milk and a commercial calf concentrate; they had access to hay from I month of age.

When the heifers were placed on experiment (Table $\mathrm{I}$ ) one member of each pair was chosen at random to receive a diet consisting of hay ad lib. and, for all except a short period of the experiment, $2 \mathrm{lb}$ concentrates daily. The second member was given a diet containing about $40 \%$ of the amount of hay eaten by the first and sufficient concentrates to keep her growing at the same rate. These diets, which will be called the high-hay and low-hay diets, respectively, were continued until the mean age of the 
animals was about 2 years and all had been inseminated; the diets were then changed temporarily while digestion trials were carried out.

During the rearing period the animals were housed in unheated farm buildings. They were tied twice daily at mangers adapted to prevent uneaten food being stolen by neighbours. The animals receiving the high-hay diet were in a pen separate from those receiving the low-hay diet and received their hay in nets which were removed when they were released at the end of the meal. The low-hay group received loose hay from sacks. Water was available at all times. During mild weather the animals were allowed exercise in a bare yard, at other times they were loose in the pens.

\section{Table 1. Code numbers of the pairs of monozygous heifer twins and dates of} significant events in the experiment

\begin{tabular}{|c|c|c|c|c|c|c|}
\hline $\begin{array}{l}\text { Pair } \\
\text { nos. }\end{array}$ & Breed & $\begin{array}{l}\text { Born, } \\
\text { 1955 }\end{array}$ & $\begin{array}{c}\text { Weaned, } \\
1955\end{array}$ & $\begin{array}{c}\text { On } \\
\text { experiment, } \\
\text { I955 }\end{array}$ & $\begin{array}{c}\text { First } \\
\text { digestibility } \\
\text { trial begun, } \\
\text { 1957 }\end{array}$ & $\begin{array}{c}\text { Diet } \\
\text { first } \\
\text { changed, } \\
\text { I } 957\end{array}$ \\
\hline $\begin{array}{l}33,34 \\
35,36 \\
39,40 \\
41,42 \\
45,46\end{array}$ & $\begin{array}{l}\text { Shorthorn } \\
\text { Shorthorn } \times \text { Friesian } \\
\text { Jersey } \\
\text { Shorthorn } \\
\text { Ayrshire }\end{array}$ & $\begin{array}{l}\text { I Jan. } \\
\text { I } 2 \text { Jan. } \\
\text { I } 2 \text { Feb. } \\
5 \text { Mar. } \\
\text { I3 Mar. }\end{array}$ & $\begin{array}{l}25 \text { Apr. } \\
\text { I8 Apr. } \\
27 \text { June } \\
27 \text { June } \\
\text { 13 June }\end{array}$ & $\begin{array}{l}25 \text { Apr. } \\
25 \text { Apr. } \\
4 \text { July } \\
\text { 4 July } \\
\text { 4 July }\end{array}$ & $\begin{array}{l}24 \text { Feb. } \\
22 \text { Mar. } \\
24 \text { Feb. } \\
22 \text { Mar. } \\
22 \text { Mar. }\end{array}$ & $\begin{array}{l}8 \text { Mar. } \\
3 \text { Apr. } \\
8 \text { Mar. } \\
3 \text { Apr. } \\
3 \text { Apr. }\end{array}$ \\
\hline
\end{tabular}

The animals were weighed weekly. Every 6 months they were measured for length (anterior edge of scapula to most posterior point of tuber ischium), height at withers, barrel (maximum girth) and chest girth. All measurements were made in duplicate on each side of the animal.

Foods. During the rearing period six different types of hay were used for varying periods as shown in Table 2.

The concentrates were a mixture of oats (7 parts) and groundnut cake (I part) with supplements of a complete mineral mixture and vitamins A and D. Salt licks were available.

All foods and any uneaten food were weighed daily. The amounts of hay offered to animals in the high-hay group, and to all animals during lactation, were adjusted weekly in an attempt to ensure that some $5^{-15} \%$ remained uneaten. The amount of hay given to a member of the low-hay group was adjusted according to the intake of the sister in the high-hay group and the amount of concentrates was adjusted according to the weight of the animal at the beginning of each week. We attempted to keep the weight of the low-hay group at about $95 \%$ of the weight of the high-hay group to eliminate the effect of differences in the weight of the gut contents.

Digestibility trials. During gestation, digestibility trials were carried out with each animal: $(a)$ on the diet on which it had been reared, $(b)$ on the diet on which the sister had been reared, and $(c)$ on a diet of hay alone. In $(a)$ and $(b)$ minor adjustments were made so that the ratio of hay to concentrates remained constant throughout each treatment group and to prevent food being left uneaten during the trials. In $(b)$ the treatments were reversed for $4^{-6}$ weeks before the digestibility trials were carried out. After the third set of trials the animals reverted to the diets on which they had been reared. 
For the determination of the digestibility of the diets, each pair of animals was transferred three times to the metabolism house. Faeces and urine were collected in 12-day collection periods by means of our usual harness (Balch, Bartlett \& Johnson, I95I), incorporating a few shortened straps for the smaller animals; analysis of the foods, faeces and urine was by standard procedures.

Lactation. Treatment ended 6 weeks before the expected calving date. From this time both animals in each pair received hay ad lib. and moderate quantities of concentrates, in order to emphasize any differences in their ability to utilize roughage. Feeding immediately before calving was at the modest levels of 2,4 and $6 \mathrm{lb}$ concentrates daily in the last three 2-weekly periods of gestation. In one pair, nos. $4 \mathrm{I}$ and 42 , this arrangement was curtailed by the premature calving of no. 42. During lactation the first heifer of each pair to calve was given concentrates in moderate quantities; our aim was $3 \mathrm{lb} / \mathrm{ro} \mathrm{lb}$ milk produced, but this amount was exceeded with some of the lower-yielding animals. The second member of a pair received the same amount of concentrates, in each week of lactation, as the first. The milk was sampled and analysed weekly by standard procedures.

\section{RESULTS}

Food intake during rearing period. The amounts consumed of each of the six types of hay and the weeks of the rearing period for which they were given are listed in Table 2 with the intakes of concentrates. The allowance of concentrates for animals in the high-hay group was $2 \mathrm{lb}$ daily except for a period with hay type $c$ when it was temporarily raised to $3 \mathrm{lb}$ in order to improve the rate of growth.

Weight of animals during rearing period. The weights of the heifers at the end of each period with a different type of hay are given in Table 3 and the mean weights of animals in the high-hay and low-hay groups in Fig. 1. These show that a mean weekly gain of about $6.6 \mathrm{lb}$ was maintained throughout rearing, which although low is not unsatisfactory in view of the poor quality of most of the hays. The attempt to maintain the weight of the low-hay group at about $95 \%$ of the weight of the high-hay group was fairly successful. At the end of the rearing period it seemed likely, therefore, that the empty body-weights of the twins on each treatment were reasonably close. It was confirmed after calving when both groups averaged ro2 $\mathrm{lb}$ on the same diet.

Body measurements. The mean values for the four body measurements made periodically during the experiment are given in Table 4. During the first few weeks of life the rumens of the high-hay group were obviously distended, giving them a 'potbellied' appearance; this distension diminished as they grew, but it was always possible to distinguish animals receiving the high-hay diet. The length, height and chest measurements were closely similar in sisters throughout the experiment. The barrel measurement was greater in all animals receiving the high-hay diet than in their sisters receiving the low-hay diet. This relationship remained when the diets were reversed for the digestion trials and is reflected in the value for week 124 in Table 4 . During lactation the barrel measurement was slightly greater in the group reared on the low-hay diet. No significance is attached to this slight difference, but it suggests 


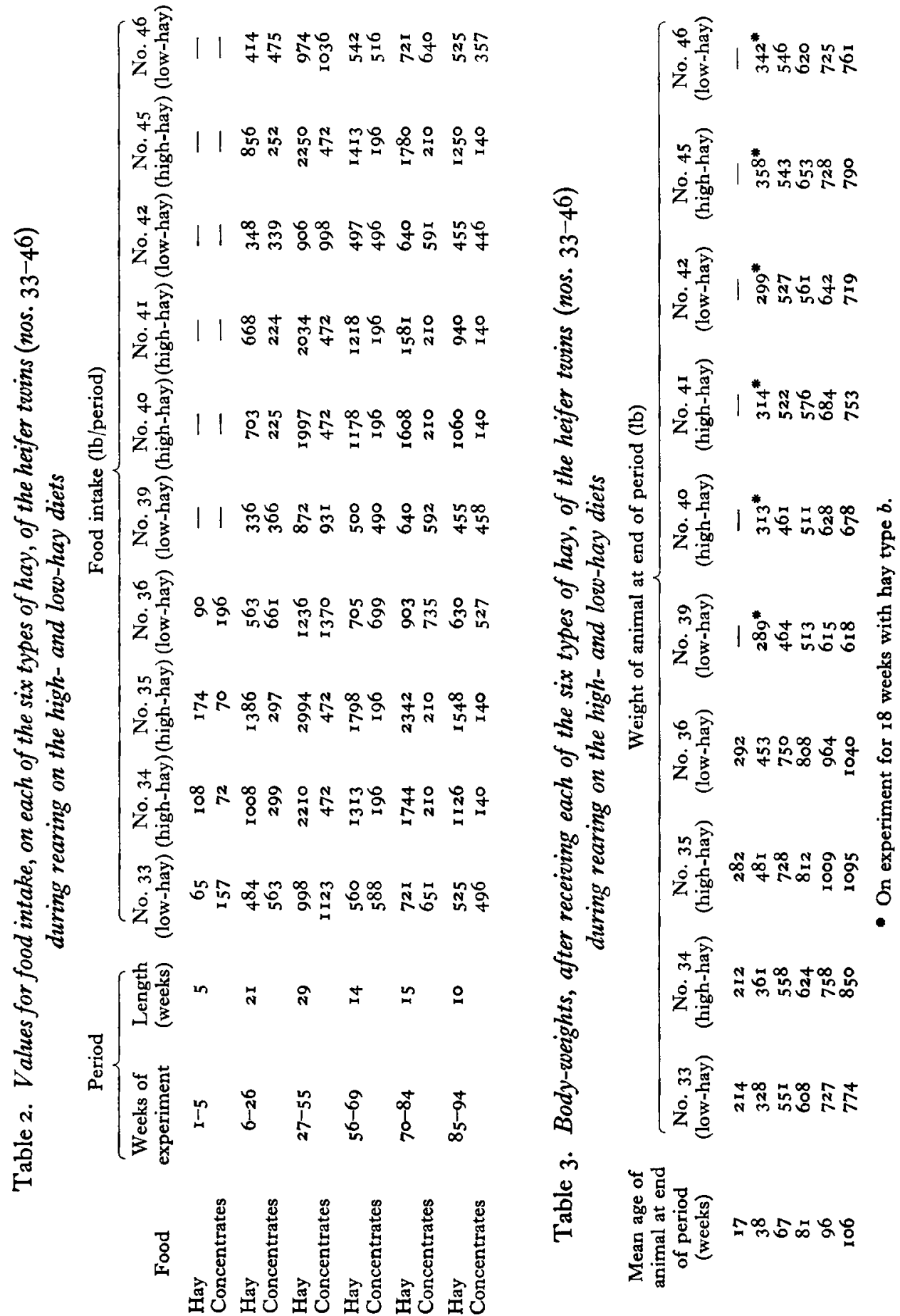

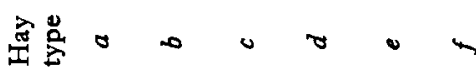


that the early distension of the rumen and the larger amounts contained therein throughout the rearing period did not cause any obvious increase in rumen capacity.

Digestibility trials. The amounts of foods consumed daily in the three digestion trials with each animal are given in Table 5 . The results are unlikely to have been influenced

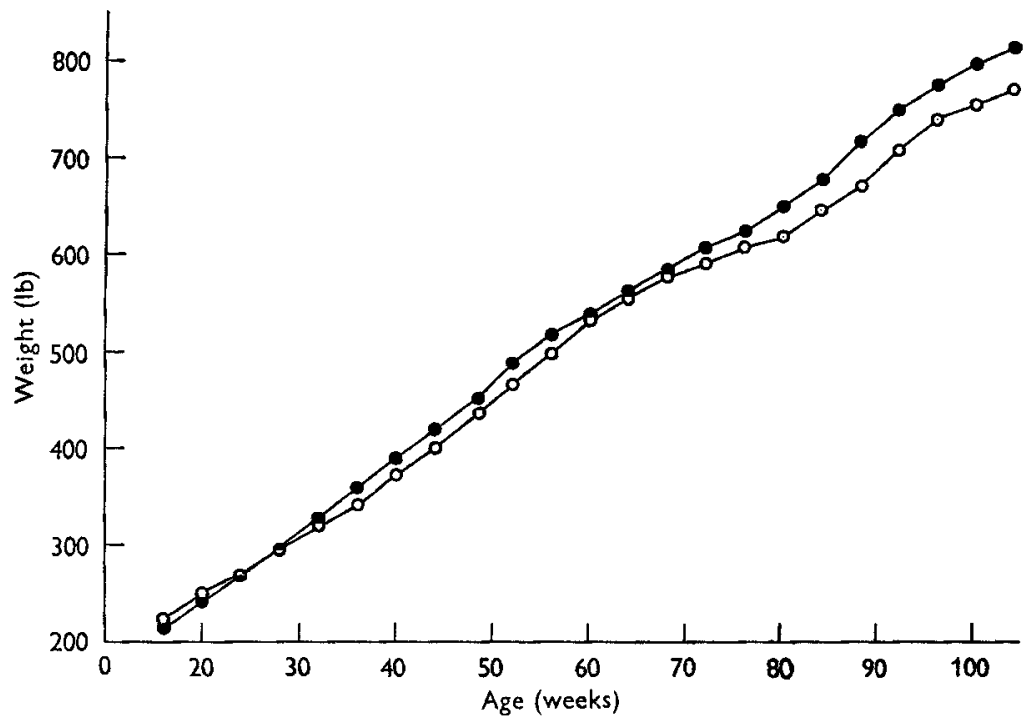

Fig. 1. Mean weight of twin heifers reared on the high-hay, $\bullet$, and low-hay, 0 , diets from end of bucket feeding until the diets were reversed for digestibility trials. Each point is a mean value for five animals during 4 weeks.

Table 4. Mean values for body measurements of the five pairs of heifers at intervals throughout the experiment

\begin{tabular}{|c|c|c|c|c|c|c|c|}
\hline \multirow{2}{*}{$\begin{array}{c}\text { Mean } \\
\text { age } \\
\text { (weeks) }\end{array}$} & \multicolumn{2}{|c|}{ Diet } & \multirow[b]{2}{*}{$\begin{array}{l}\text { Weight } \\
\text { (lb) }\end{array}$} & \multirow[b]{2}{*}{$\begin{array}{l}\text { Length } \\
\text { (in.) }\end{array}$} & \multirow[b]{2}{*}{$\begin{array}{l}\text { Height } \\
\text { (in.) }\end{array}$} & \multirow[b]{2}{*}{$\begin{array}{l}\text { Barrel } \\
\text { (in.) }\end{array}$} & \multirow[b]{2}{*}{$\begin{array}{c}\text { Chest } \\
\text { (in.) }\end{array}$} \\
\hline & $\begin{array}{l}\text { During } \\
\text { rearing }\end{array}$ & $\begin{array}{c}\text { At time of } \\
\text { measurement }\end{array}$ & & & & & \\
\hline 26 & $\begin{array}{l}\text { Low-hay } \\
\text { High-hay }\end{array}$ & Rearing & $\begin{array}{l}286 \\
274\end{array}$ & $\begin{array}{l}35^{\cdot 6} \\
34 \cdot 8\end{array}$ & $\begin{array}{l}37 \cdot 3 \\
3^{6 \cdot 5} 5\end{array}$ & $\begin{array}{l}54^{\circ} \cdot 4 \\
57^{\prime} \cdot 1\end{array}$ & $\begin{array}{l}43 \cdot 0 \\
43 \cdot 2\end{array}$ \\
\hline 52 & $\begin{array}{l}\text { Low-hay } \\
\text { High-hay }\end{array}$ & Rearing & $\begin{array}{l}492 \\
489\end{array}$ & $\begin{array}{l}42 \cdot 2 \\
42 \cdot 2\end{array}$ & $\begin{array}{l}43 \cdot 1 \\
42 \cdot 5\end{array}$ & $\begin{array}{l}63 \cdot 2 \\
68 \cdot 8\end{array}$ & $\begin{array}{l}53 \cdot 4 \\
53 \cdot 2\end{array}$ \\
\hline 78 & $\begin{array}{l}\text { Low-hay } \\
\text { High-hay }\end{array}$ & Rearing & $\begin{array}{l}625 \\
654\end{array}$ & $\begin{array}{l}47 \cdot 5 \\
47 \cdot 2\end{array}$ & $\begin{array}{l}46 \cdot 9 \\
46 \cdot 2\end{array}$ & $\begin{array}{l}69 \cdot 8 \\
74 \cdot 6\end{array}$ & $\begin{array}{l}60.0 \\
60.8\end{array}$ \\
\hline 104 & $\begin{array}{l}\text { Low-hay } \\
\text { High-hay }\end{array}$ & Rearing & $\begin{array}{l}782 \\
833\end{array}$ & $\begin{array}{l}50 \cdot 9 \\
50 \cdot 8\end{array}$ & $\begin{array}{l}48 \cdot 7 \\
48 \cdot 8\end{array}$ & $\begin{array}{l}76 \cdot 1 \\
81 \cdot 0\end{array}$ & $\begin{array}{l}65 \cdot 9 \\
67 \cdot 3\end{array}$ \\
\hline 124 & $\begin{array}{l}\text { Low-hay } \\
\text { High-hay }\end{array}$ & $\begin{array}{l}\text { Rearing, } \\
\text { reversed* }\end{array}$ & $\begin{array}{l}967 \\
920\end{array}$ & $\begin{array}{l}53 \cdot 8 \\
53 \cdot 4\end{array}$ & $\begin{array}{l}49 \cdot 7 \\
49 \cdot 8\end{array}$ & $\begin{array}{l}85 \cdot 4 \\
83 \cdot 4\end{array}$ & $\begin{array}{l}70 \cdot 1 \\
70 \cdot 4\end{array}$ \\
\hline 135 & $\begin{array}{l}\text { Low-hay } \\
\text { High-hay }\end{array}$ & Rearing & $\begin{array}{l}965 \\
997\end{array}$ & $\begin{array}{l}55^{\circ} \circ \\
55^{\circ} \cdot 2\end{array}$ & $\begin{array}{l}49 \cdot 5 \\
50 \cdot 1\end{array}$ & $\begin{array}{l}81 \cdot 6 \\
84 \cdot 8\end{array}$ & $\begin{array}{l}69 \cdot 1 \\
71 \cdot 4\end{array}$ \\
\hline I 56 & $\begin{array}{l}\text { Low-hay } \\
\text { High-hay }\end{array}$ & Lactation & $\begin{array}{r}1050 \\
987\end{array}$ & $\begin{array}{l}56 \cdot 5 \\
56 \cdot 8\end{array}$ & $\begin{array}{l}50.6 \\
50.7\end{array}$ & $\begin{array}{l}88 \cdot 6 \\
87 \cdot 2\end{array}$ & $\begin{array}{l}73 \cdot 0 \\
73 \cdot 8\end{array}$ \\
\hline
\end{tabular}




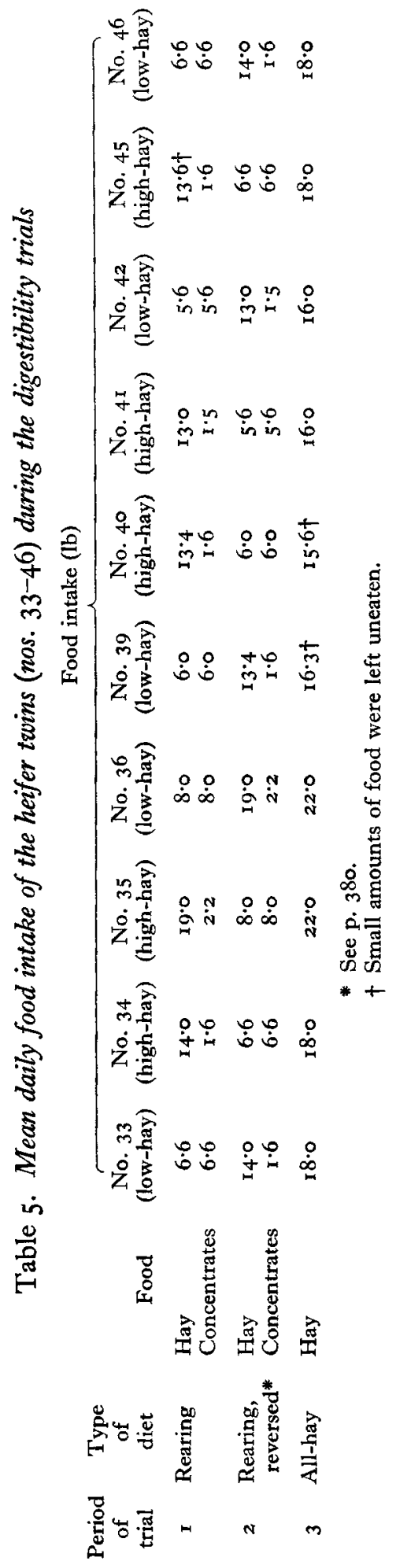


by the small amounts of the offered food left uneaten by three of the animals, since the resulting differences in the intake of twin sisters were very small.

The values listed in Table 6 leave little doubt that the diet given during the rearing period exerted no consistent effect on the ability of the heifers to digest any of the three diets tested. On the same diet differences between values for the members of a pair were no greater than might have been expected if the same diet had been given to one animal in consecutive periods. The high variability of values for ether extract, in the period when hay was given alone, is not unprecedented. It was probably due to the

Table 6. Values for digestibility and nitrogen balances on low-hay, high-hay and all-hay diets given, at the end of the rearing period, to twin heifers

\begin{tabular}{|c|c|c|c|c|c|c|c|c|c|}
\hline \multirow{2}{*}{\multicolumn{2}{|c|}{$\overbrace{}^{\text {Diet }}$}} & \multirow[b]{3}{*}{$\begin{array}{c}\text { Heifer } \\
\text { no. }\end{array}$} & \multicolumn{6}{|c|}{ Digestibility (\%) } & \multirow{3}{*}{$\begin{array}{c}\text { Nitrogen } \\
\text { balance } \\
\text { (g/day) }\end{array}$} \\
\hline & & & \multirow[b]{2}{*}{$\begin{array}{c}\text { Dry } \\
\text { matter }\end{array}$} & \multirow[b]{2}{*}{$\begin{array}{l}\text { Crude } \\
\text { protein }\end{array}$} & \multirow[b]{2}{*}{$\begin{array}{l}\text { Ether } \\
\text { extract }\end{array}$} & \multirow{2}{*}{$\begin{array}{l}\text { Nitrogen- } \\
\text { free } \\
\text { extract }\end{array}$} & \multirow[b]{2}{*}{$\begin{array}{l}\text { Crude } \\
\text { fibre }\end{array}$} & \multirow[b]{2}{*}{ Ash } & \\
\hline$\underset{\text { trial }}{\text { During }}$ & $\begin{array}{l}\text { During } \\
\text { rearing }\end{array}$ & & & & & & & & \\
\hline \multirow[t]{10}{*}{ Low-hay } & Low-hay & $\begin{array}{l}33 \\
36\end{array}$ & $\begin{array}{l}65^{\circ} 9 \\
68 \cdot 0\end{array}$ & $\begin{array}{l}65 \cdot 7 \\
71 \cdot 2\end{array}$ & $\begin{array}{l}52 \cdot 2 \\
60 \cdot 2\end{array}$ & $\begin{array}{l}70 \cdot 4 \\
72.8\end{array}$ & $\begin{array}{l}60 \cdot 8 \\
62 \cdot 8\end{array}$ & $\begin{array}{l}42 \cdot 7 \\
38 \cdot 3\end{array}$ & $\begin{array}{l}+4.8 \\
+9.2\end{array}$ \\
\hline & & 39 & $69 \cdot 5$ & $70 \cdot 5$ & $52 \cdot 0$ & $74 \cdot 5$ & $66 \cdot 3$ & $43^{\cdot I}$ & +13.2 \\
\hline & & 42 & $67 \cdot 9$ & $69 \cdot 7$ & $6 \pi \cdot 4$ & $72 \cdot 4$ & $63 \cdot 8$ & $44 \cdot 0$ & $+\mathrm{I} \cdot 7$ \\
\hline & & 46 & $66 \cdot 7$ & $68 \cdot 8$ & $55^{\cdot 8}$ & $72 \cdot 1$ & $63 \cdot 2$ & $45^{\cdot 6}$ & $+12 \cdot 6$ \\
\hline & & Mean & $67 \cdot 6$ & $69 \cdot 2$ & $56 \cdot 3$ & $72 \cdot 4$ & 63.4 & $42 \cdot 7$ & $+8 \cdot 3$ \\
\hline & High-hay & 34 & $65^{\circ} 4$ & $65 \cdot 6$ & $56 \cdot 2$ & $7 r \cdot 5$ & $\begin{array}{l}60 \cdot 7 \\
6 . \cdot 6\end{array}$ & $32 \cdot 0$ & $\begin{array}{l}+43 \cdot 1 \\
+12 \cdot 2\end{array}$ \\
\hline & & 35 & $67 \cdot 8$ & $70 \cdot 8$ & $62 \cdot 2$ & $73^{\circ} \circ$ & $6 r \cdot 6$ & & $\begin{array}{r}+12 \cdot 2 \\
-2 \cdot 1\end{array}$ \\
\hline & & 40 & $67 \cdot 2$ & $68 \cdot 1$ & $62 \cdot 4$ & $73 \cdot 4$ & $6 I \cdot 6$ & 33.5 & $\begin{array}{l}-2 \cdot 1 \\
+3 \cdot I\end{array}$ \\
\hline & & $\begin{array}{l}4 I \\
45\end{array}$ & $\begin{array}{l}69 \cdot 4 \\
70 \cdot 2\end{array}$ & $\begin{array}{l}72 \cdot 8 \\
70 \cdot 2\end{array}$ & $\begin{array}{l}62 \cdot 9 \\
62.5\end{array}$ & $\begin{array}{l}75 \cdot 1 \\
80.3\end{array}$ & $\begin{array}{l}66 \cdot I \\
66 \cdot 8\end{array}$ & $\begin{array}{l}39^{\circ} 6 \\
45^{\circ} 0\end{array}$ & $\begin{array}{l}+3 \cdot 1 \\
+2 \cdot 0\end{array}$ \\
\hline & & Mean & $\begin{array}{l}70 \cdot 2 \\
68 \cdot 0\end{array}$ & 69.5 & $61 \cdot 2$ & $\begin{array}{l}003 \\
74 \cdot 7\end{array}$ & 63.4 & $38 \cdot 5$ & $+11 \cdot 7$ \\
\hline \multirow{12}{*}{ High-hay } & & & $60 \cdot 3$ & & & $59 \cdot 6$ & $65 \cdot 2$ & & $+17^{\circ} 9$ \\
\hline & Low-hay & $\begin{array}{l}33 \\
36\end{array}$ & $\begin{array}{l}00 \cdot 3 \\
64 \cdot I\end{array}$ & $\begin{array}{l}59.9 \\
60.0\end{array}$ & $\begin{array}{l}45^{*} 4 \\
4 I^{*} 4\end{array}$ & $\begin{array}{l}59^{\circ} 0 \\
63^{\circ} 7\end{array}$ & $\begin{array}{l}05 \cdot 2 \\
71 \cdot 2\end{array}$ & $\begin{array}{l}47 \cdot 5 \\
48 \cdot 2\end{array}$ & $\begin{array}{r}+179 \\
+92\end{array}$ \\
\hline & & 39 & 65.5 & $60 \cdot 6$ & $44 \cdot 4$ & $65 \cdot I$ & $73 \cdot 5$ & $46 \cdot 9$ & +14.8 \\
\hline & & 42 & $6 \pi \cdot 6$ & 54.4 & $37 \cdot 8$ & $6 \mathrm{I} \cdot 5$ & $71 \cdot 1$ & $39 \cdot 9$ & +0.8 \\
\hline & & 46 & $64 \cdot 3$ & $57 \cdot 0$ & $43 \cdot 7$ & $64 \cdot 5$ & $72 \cdot 6$ & $45^{\circ} \circ$ & $+6 \cdot 5$ \\
\hline & & Mean & $63 \cdot 2$ & $58 \cdot 4$ & $42 \cdot 5$ & $62 \cdot 9$ & $70 \cdot 7$ & $45 \cdot 5$ & $+9 \cdot 8$ \\
\hline & High-hay & 34 & $64 \cdot 2$ & $56 \cdot 0$ & $36 \cdot 8$ & 63.4 & $\begin{array}{r}73 \cdot 2 \\
7.8\end{array}$ & $\begin{array}{l}49 \cdot 3 \\
40 \cdot 8\end{array}$ & +13.1 \\
\hline & & 35 & $64 \cdot 4$ & $63 \cdot I$ & $40 \cdot 6$ & $63 \cdot 0$ & $71 \cdot 8$ & $49 \cdot 8$ & $+32 \cdot 7$ \\
\hline & & 40 & $65 \cdot 3$ & $59^{\circ} 8$ & $37 \cdot 3$ & 65.4 & $71 \cdot 5$ & $54^{\cdot 6}$ & +8.5 \\
\hline & & $4 \mathrm{I}$ & $64 \cdot 3$ & $6 x \cdot 5$ & $39 \cdot 2$ & $62 \cdot 3$ & $72 \cdot 8$ & $50 \cdot 0$ & +13.6 \\
\hline & & 45 & $65^{\circ} \circ$ & $63 \cdot 6$ & $40 \cdot 8$ & $63 \cdot 3$ & $74 \cdot 1$ & $50 \cdot 0$ & $-2 \cdot 6$ \\
\hline & & Mean & $64 \cdot 6$ & $60 \cdot 8$ & $38 \cdot 9$ & 63.5 & $72 \cdot 7$ & $50 \cdot 7$ & +13.1 \\
\hline \multirow[t]{11}{*}{ All-hay } & Low-hay & $\begin{array}{l}33 \\
36\end{array}$ & $\begin{array}{l}59 \cdot 9 \\
57 \cdot 8\end{array}$ & $\begin{array}{l}56 \cdot 5 \\
51 \cdot 1\end{array}$ & $\begin{array}{l}45.5 \\
17 \cdot 6\end{array}$ & $\begin{array}{l}63.3 \\
60.8\end{array}$ & $\begin{array}{l}6 \mathrm{I} \cdot 3 \\
63 \cdot 5\end{array}$ & $\begin{array}{l}39 \cdot 1 \\
36 \cdot 7\end{array}$ & $\begin{array}{l}+21.8 \\
+12.6\end{array}$ \\
\hline & & 39 & $58 \cdot 2$ & 54.7 & $42 \cdot 5$ & $60 \cdot 8$ & $59 \cdot 3$ & $40 \cdot 1$ & $+\mathrm{I} 4.5$ \\
\hline & & 42 & $57 \cdot 5$ & $5 I \cdot 5$ & 15.6 & $59 \cdot 7$ & $64 \cdot 3$ & $3^{8 \cdot 8}$ & $+7 \cdot 1$ \\
\hline & & 46 & $60 \cdot 8$ & $53 \cdot 4$ & $18 \cdot 9$ & $62 \cdot 9$ & $69 \cdot 4$ & $37 \cdot 3$ & $-9 \cdot x$ \\
\hline & & Mean & $5^{8 \cdot 8}$ & $53 \cdot 4$ & $28 \cdot 0$ & $6 I \cdot 5$ & $63 \cdot 6$ & $38 \cdot 4$ & $+9 \cdot 4$ \\
\hline & High-hay & 34 & $59 \cdot 4$ & $5 I^{\circ} 9$ & $40 \cdot 2$ & $62 \cdot 7$ & $6 r \cdot 6$ & $39^{\circ} \circ$ & $\begin{array}{r}+20.9 \\
+23.8\end{array}$ \\
\hline & & 35 & $55^{\cdot 6}$ & $49 \cdot 6$ & $10 \cdot 3$ & $58 \cdot 9$ & $59^{\circ} 8$ & $36 \cdot 7$ & +23.8 \\
\hline & & 40 & $6+5$ & $58 \cdot 7$ & $48 \cdot 6$ & 63.7 & $63^{\circ} \circ$ & $44 \cdot 2$ & $+22 \cdot 0$ \\
\hline & & 41 & $57 \cdot 5$ & $49 \cdot \pi$ & $17 \cdot 6$ & $60 \cdot 3$ & $64 \cdot 3$ & $37 \cdot 5$ & +9.8 \\
\hline & & 45 & 59.9 & $53 \cdot I$ & $2 I \cdot 8$ & $62 \cdot 3$ & $66 \cdot 5$ & $40 \cdot 6$ & +15.6 \\
\hline & & Mean & 58.8 & $52 \cdot 5$ & $27 \cdot 7$ & $6 x \cdot 6$ & 63.0 & $39^{\circ} 6$ & +18.4 \\
\hline
\end{tabular}




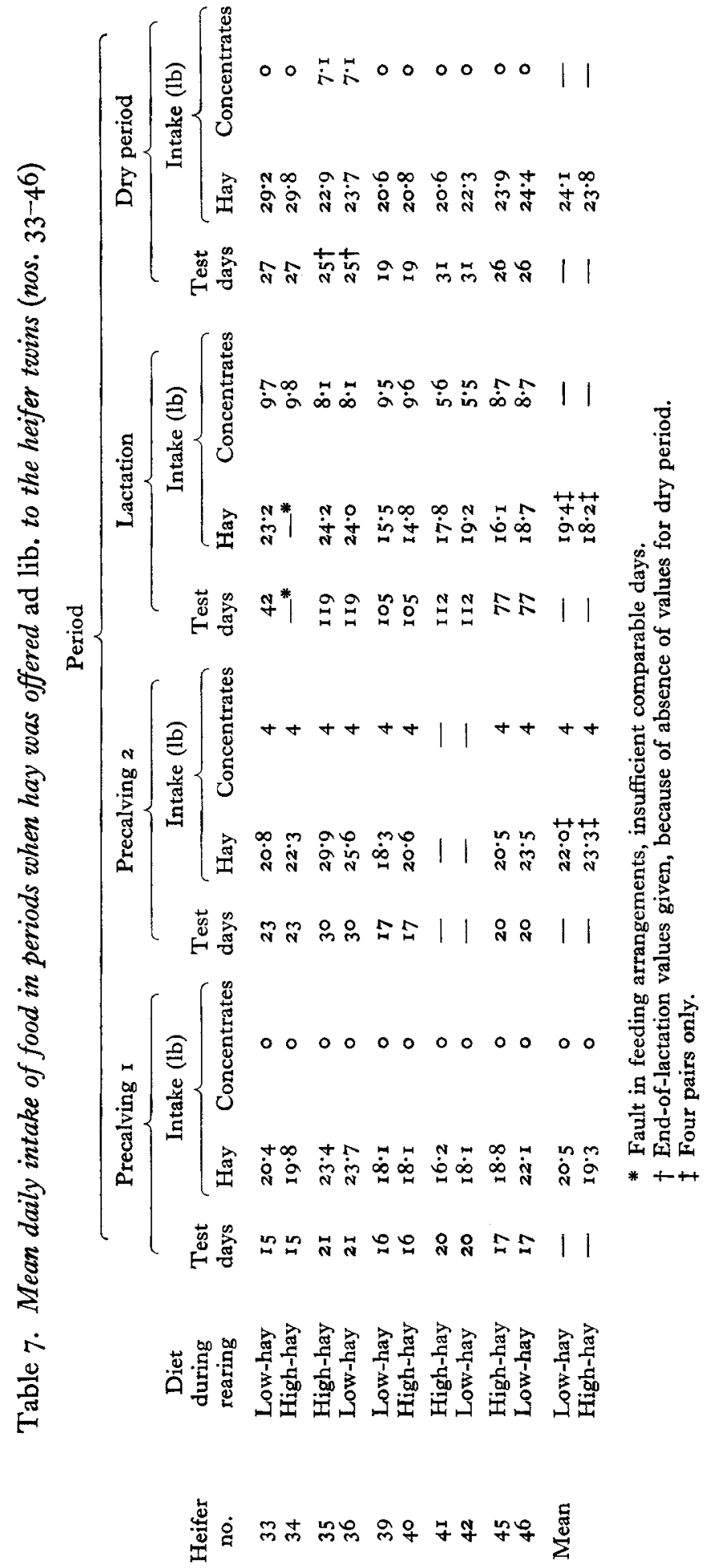


Vol. I4

Rearing methods, and digestion in adult cows

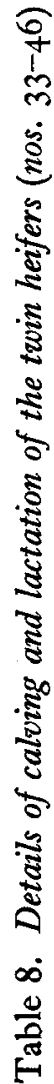
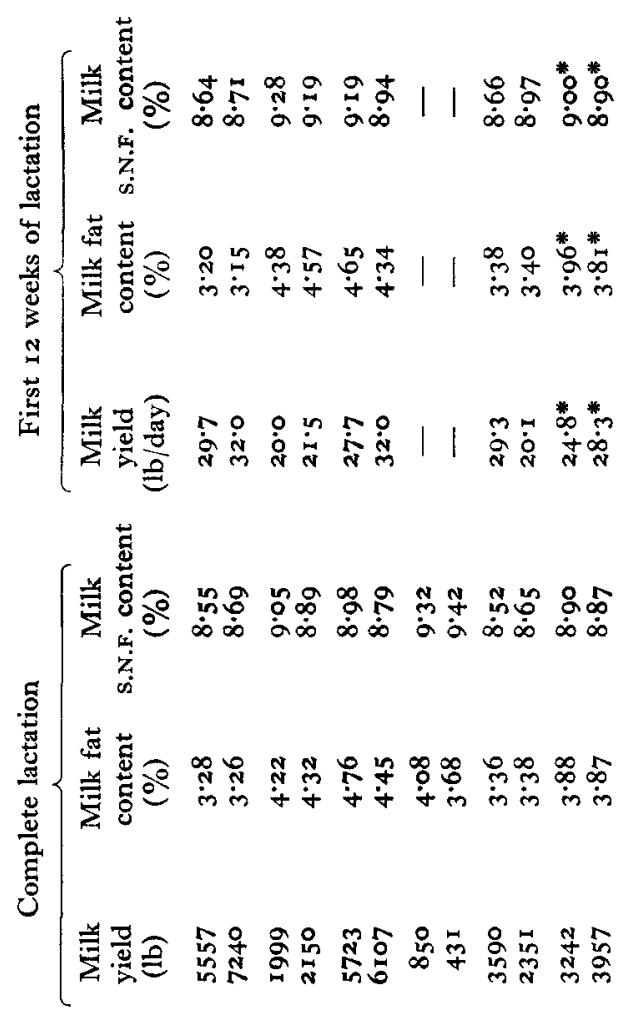

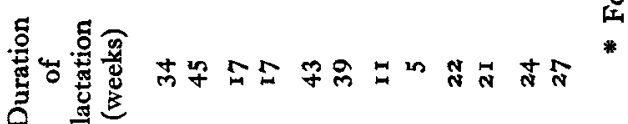

ํำ

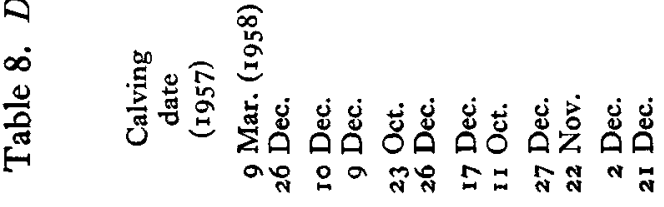

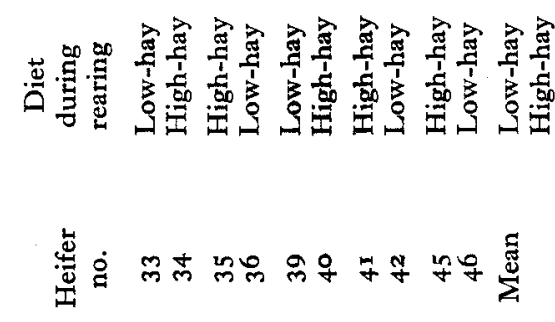


small amounts of ether-extractable material present in hay and to the marked effect on the digestibility coefficients for this fraction resulting from even small changes in the amount of it added to the gut contents as secretions and cellular debris.

During the digestibility trials nitrogen balances were very variable (Table 6), so that although the mean values for animals reared on the high-hay diet were the greater it is most improbable that these differences had any real meaning.

Appetite for roughages. During the preliminary periods in the last digestibility trials (precalving period $\mathrm{I}$ in Table 7), during the immediate precalving period (precalving period 2), during lactation and during the dry period following lactation opportunities were provided for comparing the amount of hay consumed when both twins of a pair were offered it ad lib. The values given in Table 7 show, in general, the mean intake on days when both members of a pair left food uneaten; the values for the lactation period include all days even if no food was left uneaten. The type of hay was changed during these tests, but in any one period values for the two twins of a pair are exactly comparable; no significance should be attached, however, to differences in the same animal in different periods. The values suggest that the method of rearing had no effect on subsequent appetite for hay.

Calving and lactation. Values summarized in Table 8 show that the considerable efforts made to secure conceptions within a short period were unsuccessful and the calving dates of the members of a pair of twins varied by as much as ro weeks. The weights of the calves born to each member of the pairs differed by $3 \mathrm{lb}$ or less, apart from the premature calf of heifer no. 42.

The milk yields of two of the pairs of heifers were satisfactory, but those of the other pairs were very poor; heifer no. $4 \mathrm{I}$ was in milk for only I I weeks and the sister, the premature calver no. 42 , for only 5 weeks. Heifer no. 46 was very difficult to milk and required several weeks to learn to release her milk properly during milking, which undoubtedly affected her performance.

Because of these several complications no firm conclusions can be drawn from the lactation records and it would be unwise to place any especial significance on either the rather higher mean yield, $3957 \mathrm{lb}$, of the heifers reared on the high-hay treatment compared with those reared on the low-hay diet, $3242 \mathrm{lb}$, or the greater yield in the first I2 weeks of lactation. The method of rearing undoubtedly exerted no effect on the composition of the milk.

The general level of production of these monozygous twins was disappointing, but was not very different from the average for such twins collected in this area.

\section{DISCUSSION}

The values for food intake, body-weight and body size show that the two rearing systems were successfully modified to produce two groups of animals closely similar in size; use of monozygous twins ensured that the groups were alike genetically. The two diets used for rearing may be taken to represent the extremes, in level of hay intake, likely to be met in farm practice in Britain. The rearing periods did not include, however, the one or two periods of grazing that would occur in practice and that might 
be expected to modify the effect of any diet given while the animals were indoors. Since the results showed no differences in the appetite of the adult animals for roughages, or in their ability to digest three diverse diets, it seems most unlikely that differences of any appreciable size would be found under farm conditions. It is of interest that in an experiment in which monozygous twins were reared at different planes of nutrition, and consequently varied considerably in their weights at first calving, the digestive ability of the animals was not altered by the method of rearing (Hansson, Brännäng \& Claesson, 1953). In this Swedish experiment and in similar large American (Reid, Loosli, Turk, Asdell \& Smith, 1957) and Danish (Hansen \& Steensberg, 1950) experiments the method of rearing exerted a considerable effect on subsequent milk yields, animals reared on low planes tending to give more milk than others reared on higher planes.

The present experiment only covered the main rearing period from about 4 months to 2 years of age. At the present time there is widespread practical interest in the early weaning and early introduction to solid food of calves. Certain of the factors governing the early histological development of the reticulo-rumen have received attention (Brownlee, 1956; Warner, Flatt \& Loosli, 1956; Flatt, Warner \& Loosli, I958), but it is not yet known to what extent an early histological development of the rumen influences the digestive efficiency of the adult ruminant. This question, which was not examined in the present experiment, merits attention.

The reasonably successful control of the growth rate of the low-hay group to match that of the high-hay group could have been improved with more frequent weighing of the animals. This type of feeding control may have uses in the assessment of the relative values of different foods.

It was unfortunate that two mishaps at calving made it impossible to draw any firm conclusions about the effect of the treatment on milk production. In the three pairs of twins remaining unaffected by these troubles it seemed unlikely that there was any marked effect on milk yield or composition. The arrangement of closely similar calving dates is probably often the most crucial factor in carrying out experiments with lactating monozygous twins.

\section{SUMMARY}

I. The effect of two levels of hay in a rearing diet of hay and concentrates on the appetite and digestive efficiency of adult cattle was investigated in an experiment with five pairs of monozygous twins. One of each pair was given the high-hay diet, consisting of $2 \mathrm{lb}$ concentrates daily and hay $a d$ lib., and the other the low-hay diet, containing about $40 \%$ of this amount of hay and sufficient concentrates to keep both members of the pair growing at the same rate. These diets were given from weaning until 6 weeks before calving, with a break during the first gestation for digestibility trials.

2. In the digestion trials each animal received $(a)$ the diet on which it had been reared, $(b)$ the diet on which its sister had been reared and $(c)$ an all-hay diet, in that order.

3. The weight and body measurements of the heifers showed that, apart from 
increased filling of the rumen in any animals receiving the high-hay diet, the two members of each twin pair remained closely similar in size.

4. The method of rearing had no subsequent effect on either the digestive ability or appetite of the animals for hay.

5. Mishaps at calving and a general disappointing level of production precluded any conclusions on the effect of the rearing diets on milk yields; there appeared to be no effect on milk composition.

Our thanks are due to the many workers at the Institute's High Copse and Arborfield Hall farms who helped with the rearing stage of this experiment, and especially to Messrs R. H. Gilbert, R. M. Hamblin and P. S. C. Clarke. We are grateful to Dr M. J. Head for carrying out the chemical analyses.

\section{REFERENCES}

Balch, C. C., Bartlett, S. \& Johnson, V. W. (1951). F. agric. Sci. 41, 98.

Balch, C. C., Campling, R. C., Johnson, V. W. \& Roy, J. (1958). Proc. Nutr. Soc. I7, xlvi.

Balch, C. C., Campling, R. C., Johnson, V. W. \& Roy, J. (1959). Proc. int. Dairy Congr. xv. London, $\mathbf{x}, \mathbf{1 7 8 .}$

Brownlee, A. (1956). Brit. vet. F. 112, 369.

Flatt, W. P., Warner, R. G. \& Loosli, J. K. (1958). F. Dairy Sci. 41, 1593.

Hansen, K. \& Steensberg, V. (1950). Beretn. Forsøgslab. Kbh. no. 246.

Hansson, A., Brännäng, E. \& Claesson, O. (1953). Acta agric. Scand. 3, 6r.

Reid, J. T., Loosli, J. K., Turk, K. L., Asdell, S. A. \& Smith, S. E. (1957). 7. Dairy Sci. 40, 6ro.

Warner, R. G., Flatt, W. P. \& Loosli, J. K. (1956). F. agric. Fd Chem. 4, 788. 